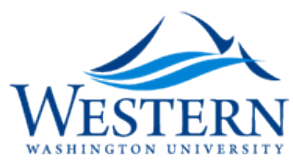

Western Washington University Western CEDAR

2006

\title{
Embracing the Power of Archives
}

Randall C. Jimerson Western Washington University

Western Washington University, randall.jimerson@wwu.edu

Follow this and additional works at: https://cedar.wwu.edu/history_facpubs

Part of the Archival Science Commons

\section{Recommended Citation}

Jimerson, Randall C. Western Washington University, "Embracing the Power of Archives" (2006). History Faculty and Staff Publications. 65.

https://cedar.wwu.edu/history_facpubs/65

This Article is brought to you for free and open access by the History at Western CEDAR. It has been accepted for inclusion in History Faculty and Staff Publications by an authorized administrator of Western CEDAR. For more information, please contact westerncedar@wwu.edu. 
Embracing the Power of Archives

Author(s): Randall C. Jimerson

Source: The American Archivist, Vol. 69, No. 1 (Spring - Summer, 2006), pp. 19-32

Published by: Society of American Archivists

Stable URL: http://www.jstor.org/stable/40294309

Accessed: 05-10-2015 16:35 UTC

\section{REFERENCES}

Linked references are available on JSTOR for this article:

http://www.jstor.org/stable/40294309?seq=1\&cid=pdf-reference\#references_tab_contents

You may need to log in to JSTOR to access the linked references.

Your use of the JSTOR archive indicates your acceptance of the Terms \& Conditions of Use, available at http://www.jstor.org/page/ info/about/policies/terms.jsp

JSTOR is a not-for-profit service that helps scholars, researchers, and students discover, use, and build upon a wide range of content in a trusted digital archive. We use information technology and tools to increase productivity and facilitate new forms of scholarship. For more information about JSTOR, please contact support@jstor.org. 


\title{
Embracing the Power of Archives
}

\author{
Randall C. Jimerson
}

In my dream I am entering a temple. Its ormate façade and tall spires give me hope. I will find enlightenment here. I push open the massive door and enter. The door clangs shut behind me. I am in a dimly lit room with high windows that prevent the sunlight from reaching me. Despite the heat outside it is cool here. A security guard approaches. The temple has become a prison.

The guard tells me to surrender my pens and put my briefcase in a locker. I sit at a table. Guards and security cameras watch me constantly to prevent escape or theft. I realize that I am hungry. A young woman hands me a menu. The prison is now a restaurant.

"What do you want?" the waitress asks. The menu she hands me does not list food items, only the names of food creators-General Mills, Vlasic Foods International, Kraft Foods, Hormel. "May I suggest something local?" She pulls down a menu for Touch of the Bayou, Inc. It lists a series of categories, including the Bayou Magic brand. "Bring me some Bayou Magic, please," I politely request.

Soon a cart arrives laden with several boxes. My food must be inside. I open one box at a time-correspondence, reports, financial ledgers. In the last box are recipes. Gumbo. Crawfish étouffé. Jambalaya.

The waitress recommends Gumbo. She brings me a box filled with okra, cayenne peppers, onions, garlic, tomatoes, and other primary sources of nutrition. After all this, I still have to cook my own meal.

Images of Archives

Changing images of the archives, as sites of power. The temple reflects the power of authority and veneration. The prison wields the power of control. The

This is the full text of a shorter paper given as the $69^{\text {th }}$ Presidential Address at the Society of American Archivists Annual Meeting in New Orleans on 18 August 2005.

The American Archivist, Vol. 69 (Spring/Summer 2006 ) : $19-32$ 
restaurant holds the power of interpretation and mediation. These represent the trinity of archival functions: selection, preservation, and access. The archives is a place of knowledge, memory, nourishment, and power. Archives at once protect and preserve records; legitimize and sanctify certain documents while negating and destroying others; and provide access to selected sources while controlling the researchers and conditions under which they may examine the archival record. As Eric Ketelaar has stated, both architecturally and procedurally, archives often resemble temples and prisons, two seemingly opposite sites of power. ${ }^{1}$ Archives embody these contradictions, and more.

Both George Orwell and George Lucas recognized that archives represent power. In his novel 1984 , Orwell declared:

Who controls the past, controls the future; who controls the present, controls the past. ... The mutability of the past is the central tenet of Ingsoc. Past events, it is argued, have no objective existence, but survive only in written records and in human memories. The past is whatever the records and the memories agree upon. And since the Party is in full control of all records, and in equally full control of the minds of its members, it follows that the past is whatever the Party chooses to make it. ${ }^{2}$

Orwell repeatedly lamented the fragmentary record of the past and the resulting gaps in our knowledge of historical events. In a 1943 essay he wrote, "When I think of antiquity, the detail that frightens me is that those hundreds of millions of slaves on whose backs civilization rested generation after generation have left behind them no record whatever." ${ }^{3}$ This was also a very personal concern. In his memoir of the Spanish Civil War, Orwell stated, "It will never be possible to get a completely accurate and unbiased account of the Barcelona fighting, because the necessary records do not exist. Future historians will have nothing to go upon except a mass of accusations and party propaganda." 4 The silences of the archives, the absence of records, most troubled Orwell.

George Lucas presents a more confident view of archives. In Star Wars, Episode II: Attack of the Clones, Jedi Master Obi Wan Kenobi visits the Jedi Temple Archives seeking the location of the planet Kamino. Archivist Madame Jocasta $\mathrm{Nu}$, a frail elderly woman, provides reference assistance, but Kamino does not appear on the archives' star charts. She concludes:

\footnotetext{
${ }^{1}$ Eric Ketelaar, "Archival Temples, Archival Prisons: Modes of Power and Protection," Archival Science 2 (2002): 221-38.

${ }^{2}$ George Orwell, 1984, quoted in Helen Willa Samuels, "Who Controls the Past," American Archivist 49 (Spring 1986): 109.

${ }^{3}$ George Orwell, A Collection of Essays (Garden City, N.Y.: Doubleday Anchor Books, 1954), 206.

${ }^{4}$ George Orwell, Homage to Catalonia (Boston: Beacon Press, 1952), 150.
} 
"I hate to say it, but it looks like the system you're searching for doesn't exist."

"That's impossible-perhaps the archives are incomplete."

"The Archives are comprehensive and totally secure, my young Jedi," came the imposing response, the Archivist stepping back from her familiarity with Obi-Wan and assuming again the demeanor of archive kingdom ruler.

"One thing you may be absolutely sure of: If an item does not appear in our records, it does not exist." The two stared at each other for a long moment, Obi-Wan taking note that there wasn't the slightest tremor of doubt in Jocasta Nu's declaration. ${ }^{5}$

It turns out, by the way, that the existence of the missing planetary system had been erased, in an act of archival sabotage. The Jedi Archives may seem "comprehensive and totally secure" but even this futuristic vision shows the limits of archival control. The archivist's pose of omniscience is truly an illusion. ${ }^{6}$ However, as Eric Ketelaar points out, the fact that Obi-Wan must physically enter the Jedi Archives in his search shows the power of the archivist, who must mediate "between brain and source." The role of the archivist is crucial and powerful.

\section{The Illusion of Neutrality}

However much we protest our objectivity and neutrality, as archivists we cannot avoid casting our own imprint on these powerful sources of knowledge. Since the emergence of "scientific history" in the nineteenth century, historians have relied on archives and other primary sources to buttress their interpretations of the past. "Through the seminar, invented in the 1830 s by a German professor of history, Leopold von Ranke, the master teacher taught the techniques of reading and dissecting historical documents," as Joyce Appleby, Lynn Hunt, and Margaret Jacob explain. "Students learned to compare the documents rigorously; newly opened state and church archives became places where truth might be found through an interrogation of document after document." 8 The archives would be a scientific laboratory for historical investigation. Hilary Jenkinson stated the archivist's ideal of objectivity, neutrality, and passivity in 1922:

\footnotetext{
${ }^{5}$ Quoted in Ketelaar, “Archival Temples," 221-22; see also Star Wars Web site: http://www.starwars.com/ databank/location/jediarchives/, accessed 4 August 2005.

${ }^{6}$ See Mary Jo Pugh, "The Illusion of Omniscience: Subject Access and the Reference Archivist," in A Modern Archives Reader, ed. Maygene Daniels and Timothy Walch (Washington, D.C.: National Archives Trust Fund Board, 1984), 264-77.

${ }^{7}$ Ketelaar, "Archival Temples," 223.

${ }^{8}$ Joyce Appleby, Lynn Hunt, and Margaret Jacob, Telling the Truth about History (New York: W. W. Norton, 1994), 73.
} 
The Archivist's career is one of service. He exists in order to make other people's work possible. ... His Creed, the Sanctity of Evidence; his Task, the Conservation of every scrap of Evidence attaching to the Documents committed to his charge; his aim to provide, without prejudice or after-thought, for all who wish to know the Means of Knowledge. ... The good Archivist is perhaps the most selfless devotee of Truth the modern world produces. ${ }^{9}$

As Elisabeth Kaplan points out, Jenkinson's appeal to nineteenth-century canons of positivism - even after the twentieth-century thinking of Einstein and Freud, among others-seems in retrospect "a stunningly reactionary statement." 10 Yet nearly a century later this is still the ideal held up to us by many of our colleagues. Even if we were to accept the possibility of such neutrality and objectivity, do we really want to be obsequious Uriah Heeps, handmaidens to history? I hope we have higher aspirations. We certainly should have more selfrespect than this. If we pride ourselves on our humility we may end up like the man given a small medal as the most humble person in town. He had it taken away when he was seen wearing the medal in public.

The postmodernist perspective only recently seeped into the American archival discourse, but it has already influenced our perspective on the traditional core values of archives. As one scholar explains, "Postmodernism calls into question Enlightenment values such as rationality, truth, and progress, arguing that these merely serve to secure the monolithic structure of modern ... society by concealing or excluding any forces that might challenge its cultural dominance."11 There is a fundamental, if unpleasant, truth in this postmodernist critique. Unfortunately it is obscured in writings of many postmodernists by jargon, convoluted syntactical gyrations, and a good dose of claptrap. As the postmodernist Godfather seems to say: "I'll make you an offer you can't understand."

Archives are not neutral or objective. We heard this before the postmodernists arrived, but they have reinforced our awareness of this problem. In 1970, Howard Zinn, the radical historian, told an audience of archivists that the archivist's "supposed neutrality" was "a fake." "The archivist, even more than the historian and the political scientist, tends to be scrupulous about his neutrality, and to see his job as a technical job, free from the nasty world of political interest: a job of collecting, sorting, preserving, making available, the records of the society," Zinn declared. However, he continued, "the existence, preservation, and availability of archives, documents, records in our society are very much

\footnotetext{
${ }^{9}$ Hilary Jenkinson, quoted in Elisabeth Kaplan, “'Many Paths to Partial Truths': Archives, Anthropology, and the Power of Representation," Archival Science 2 (2002): 215.

${ }^{10}$ Kaplan, "Many Paths," 215-16.

${ }^{11}$ Michael Fegan, quoted in Mark Greene, Midwestern Archives Conference paper, unpublished, October 2004.
} 
determined by the distribution of wealth and power." Zinn added that archival collections were "biased towards the important and powerful people of the society, tending to ignore the impotent and obscure."12 Such bias derives from the basic assumptions of archival practice. It is not conscious or deliberate. It is endemic.

The anthropologist Claude Lévi-Strauss clearly linked written documents to economic and political power. "The only phenomena which, always and in all parts of the world, seems to be linked with the appearance of writing . . . is the establishment of hierarchical societies, consisting of masters and slaves, and where one part of the population is made to work for the other part," he stated in 1961. Writing in early societies "was connected first and foremost with power: it was used for inventories, catalogues, censuses, laws and instructions . . . to keep check on material possessions or on human beings." 13 As Carolyn Steedman points out, ". . the European archive came into being in order to solidify and memorialize first monarchical, and then state power."14 Even the later founding of our National Archives in 1934 legitimized democratic institutions and ideas of popular power. These power relationships in archives affect private as well as public repositories. As Patrick Quinn wrote more than thirty years ago, "Many traditional notions of what types of primary source materials should be collected and from what sectors of the population source materials should be solicited encouraged an elitist approach to writing history, an approach that in effect ignored the history of blacks and other minorities, women, working people and the poor."15

In its most useful application to archival theory, postmodernism extends this understanding of the power relationships that exist in archives. As Terry Cook and Joan Schwartz have pointed out, "The records emerging from the creation process are anything but natural, organic, innocent residues of disinterested administrative transactions. Rather they are value-laden instruments of power." ${ }^{16}$ Elisabeth Kaplan found that although anthropologists and archivists claim to be "disinterested selectors," both serve as "intermediaries between a subject and its later interpreters, a function/role that is one of interpretation itself." Echoing George Orwell, Kaplan concluded that, "This power over the

${ }^{12}$ Howard Zinn, "Secrecy, Archives, and the Public Interest," Midwestern Archivist 2, no. 2 (1977): 20-21.

${ }^{13}$ Claude Lévi-Strauss, quoted in Steven Lubar, "Information Culture and the Archival Record," American Archivist 62 (Spring 1999): 18-19.

${ }^{14}$ Carolyn Steedman, quoted in Francis X. Blouin, Jr., "Archivists, Mediation, and Constructs of Social Memory," Archival Issues 24, no. 2 (1999): 105.

${ }^{15}$ Patrick M. Quinn, “Archivists and Historians: The Times They Are A-Changin'," Midwestern Archivist 2, no. 2 (1977): 8.

${ }^{16}$ Terry Cook and Joan M. Schwartz, "Archives, Records, and Power: From (Postmodern) Theory to (Archival) Performance," Archival Science 2 (2002): 178. 
evidence of representation, and the power over access to it, endows us with some measure of power over history, memory, and the past." ${ }^{17}$ Such power in the archives carries with it a significant measure of responsibility. If the adage that power corrupts is true, we must be on our guard.

Recognizing this power that we wield in the universe of knowledge, some of us will be tempted to seek pseudoscientific methods of distancing ourselves from our decisions. We want to believe in our neutrality. When exposed with our hands on the controls, we may wish to echo the Wizard of $\mathrm{Oz}$, who told Dorothy and her friends, "Pay no attention to the man behind the curtain!"

Rather than hide from our power in the realm of history, memory, and the past, I hope that we will embrace the power of archives and use it for the good of humankind. Before looking at the responses to this challenge of using archival power, we need to understand some of its manifestations. I would like to discuss briefly three aspects of the power of archives:

- The temple: control over social (collective) memory;

- The prison: control over preservation and security of records;

- The restaurant: the archivist's role as interpreter and mediator between records and users.

\section{The Temple}

In the archival temple, records of human activity achieve authority and immortality (or at least its semblance). The very acts of selection and preservation set some records apart from others and give them heightened validity. They represent evidence, information, truth, and social memory. "Archivists need to realize that appraisal is part of a larger process of building public memory and a process of connecting to other societal events related to the past," Richard Cox reminds us. ${ }^{18}$ As Michel-Rolph Trouillot states in Silencing the Past, the "making of archives involves a number of selective operations: selection of producers, selection of evidence, selection of themes, selection of procedures-which means, at best the differential ranking and, at worst, the exclusion of some producers, some evidence, some themes, some procedures." Trouillot continues: "History does not belong only to its narrators, professional or amateur. While some of us debate what history is or was, others take it in their own hands." 19 I take this as a call for action by archivists.

\footnotetext{
${ }^{17}$ Kaplan, "Many Paths," 211.

${ }^{18}$ Richard J. Cox, No Innocent Deposits: Forming Archives by Rethinking Appraisal (Lanham, Md.: Scarecrow Press, 2004), 40-41.

${ }^{19}$ Michel-Rolph Trouillot, quoted in Cox, No Innocent Deposits, 41.
} 
Archivists have long recognized that we are somehow in the "memory business," but we have not always understood our role or the extent of our job description. The idea that archivists play a role in shaping public memory, Cox suggests, should affect "the identification of what records should reside within the archives or be designated as archival in value." He sees archives as "a symbolic way station on the road to a collective memory." ${ }^{20}$ What we preserve in our archives represents a complex array of social values. As Elisabeth Kaplan argued in an essay on archives and the construction of identity, "We are what we collect, we collect what we are."21 By preserving some records and not others, archivists affect society's collective understanding of its past, including what will be forgotten.

Archives, however, do not constitute the past, nor our social memory of the past. René Magritte reminded us of this distinction with his famous painting of a curved pipe, under which he wrote "Ce n'est pas une pipe." In fact it was not a pipe, only a painted representation of a pipe. We should not confuse archives-or history-with memory. In fact, after researching his mother's stories of growing up in Ireland, historian Richard White cautioned, "History is the enemy of memory. ... When left alone with memories, historians treat them as detectives treat their sources: they compare them, interrogate them, and match them one against the other." 22 Archival sources proved many of White's mother's memories to be false.

In this summer's blockbuster novel, Harry Potter and the Half-Blood Prince, Professor Dumbledore promises to help the young wizard learn the secrets of his past by accompanying him into the Pensieve, a magical device into which people's thoughts and memories can be downloaded-to be retrieved or explored later. As they set out, Dumbledore warns Harry, "I told you everything I know. From this point forth, we shall be leaving the firm foundation of fact and journeying together through the murky marshes of memory into thickets of wildest guesswork." ${ }^{23}$ As archivists, of course, we recognize that what Hogwarts School needed was a good archives.

Archives help us clarify the "murky marshes of memory" and substitute documentation for guesswork. What archives provide is the record of an agreement made at a certain time, by one or more persons, about individual actions, events, and stories. Archives do not testify to the accuracy or truth of these accounts, as Luciana Duranti has argued in her study of diplomatics, but rather to the accuracy of how and when the account was created. ${ }^{24}$ Collectively, these

\footnotetext{
${ }^{20}$ Cox, No Innocent Deposits, 234.

${ }^{21}$ Elisabeth Kaplan, "We Are What We Collect, We Collect What We Are: Archives and the Construction of Identity," American Archivist 63 (Spring/Summer 2000): 126-51.

${ }^{22}$ Richard White, Remembering Ahanagran: A History of Stories (New York: Hill and Wang, 1998), 4.

${ }^{23}$ J. K. Rowling, Harry Potter and the Half-Blood Prince (New York: Scholastic, 2005), 197.

${ }^{24}$ Luciana Duranti, “Diplomatics: New Uses for an Old Science," Archivaria 28 (Summer 1989): 7-27.
} 
records of the past provide a corrective for human memory, a surrogate that remains unchanged while memory constantly shifts and refocuses its vision of the past. Although the documents and images in archival records do not visibly change, however, the postmodernists remind us that our understanding and interpretation of them do repeatedly shift and refocus.

\section{The Prison}

The second site of archival power is the archival prison. From locked doors to researchers' lockers, from closed stacks to reading room surveillance cameras, archives often resemble prisons. The records are imprisoned (for their own security, of course), but so are the researchers, who must consult records in closely guarded chambers under vigilant surveillance. For a visual icon, recall the researcher in Citizen Kane, who consults the family records in the Thatcher Library, a barren, high-ceilinged room as intimidating as any dungeon. Thirty years ago the Library of Congress Manuscripts Division actually had an armed guard, pistol in his holster, perched on a platform overlooking the research room.

Eric Ketelaar compares the archival reading room to Jeremy Bentham's panopticon, "a prison where the inmates were kept under constant surveillance (pan-optical) by guards in a central control tower." The noble arguments for preservation and secrecy, Ketelaar suggests, are "rationalizations of appropriation and power." As Martha Cooley's fictional archivist admits: "As an archivist I have power over other people. I control access to materials they desire. Of course this power has limits. . . . A good archivist serves the reader best by maintaining ... a balance between empathy and distance." Control equals power. "The surveillance and discipline are ingrained in the archivists' professional distrust of anyone other than the archivist using the archives," Ketelaar concludes. "The rituals, surveillance, and discipline serve to maintain the power of the archives and the archivist." 25

This element of archival control also extends to the processes of arrangement and description. Wendy Duff and Verne Harris observe: "In naming, we bring order to chaos. We tame the wilderness, place everything in boxes, whether standard physical containers or standardized intellectual ones. In the realm of descriptive standardization, using big boxes such as fonds or series, or small boxes such as dates of creation or acquisition, we bring order to wild realities." ${ }^{26}$ Archivists thus imprison not only their boxes of records and their

\footnotetext{
${ }^{25}$ Ketelaar, “Archival Temples," 227, 236-37. Cooley quoted page 236.

${ }^{26}$ Wendy M. Duff and Verne Harris, "Stories and Names: Archival Description as Narrating Records and Constructing Meanings," Archival Science 2 (2002): 282.
} 
researchers, but also the meanings of the archival records and identities of their creators. The archivist wields a power of interpretation over the records in his or her custody-a term usually reserved for those arrested by the police-and thus controls and shapes the meaning of these imprisoned sources.

\section{The Restaurant}

This power of interpretation appears most strongly in the archives as a restaurant, where those hungry for truth or knowledge seek nourishment. Archival power governs the research process, from the finding aids that may at first appear to be strange and exotic menus of choices difficult for the first-time customer to interpret, to the one-on-one consultation by which archivists mediate between user and document. Just look at our menus! We reduce the complex life story of a person to a "Bioghist" element and the complexities of thousands of documents to a "Scopecontent" note. As interpreters of the menu, we mediate between the customer and the records.

As Terry Cook and Joan Schwartz point out, the archivist plays a carefully scripted role in this research drama, since "the practice of archives is the ritualized implementation of theory, the acting out of the script that archivists have set for themselves." ${ }^{27}$ Typically, archivists do not even recognize that they are playing a carefully designed role in a performance through which the researcher and the archivist interact. Cook and Schwartz contend that the archivist plays a critical part "as mediator and interpreter, as an important shaper of the documentary record of the past that will be passed to the future. The archivist is an actor, not a guardian; a performer, not a custodian." They conclude: "The archival performance should not only be consciously acknowledged, but enthusiastically celebrated." 28 It is this theatrical role that endows the archivist with authority and power. In the archival restaurant, the waitress welcomes the customer, interprets the menu, suggests an entrée or dessert, and collects the money before the customer exits. It is a service role, but it comes with a measure of power and requires a reassuring smile if one wants a generous tip.

Archivists think of themselves as neutral, objective, and passive, lacking power. There is a Rodney Dangerfield strain in archival discourse. "I don't get no respect," we whine. But if knowledge is power, we have more than our share. What we need to do, as Richard Cox reminds us, is transfer some of the power within the records to the records professionals and their repositories. ${ }^{29}$

\footnotetext{
${ }^{27}$ Cook and Schwartz, "Archives, Records, and Power," 173.

${ }^{28}$ Cook and Schwartz, "Archives, Records, and Power," 183.

${ }^{29}$ Cox, No Innocent Deposits, 35.
} 


\section{Embracing Power}

Our challenge is to embrace the power of archives and to use it well. The Jedi archivist should heed the wisdom of Yoda: "A Jedi uses the Force for knowledge and defense, never for attack." Archivists can also use the Force to make society more knowledgeable, more tolerant, more diverse, and more just.

The first step is to abandon our pretense of neutrality. As Allan Spear, a professor of history and Minnesota state senator, told an SAA audience in 1983, "The concepts of neutrality and objectivity are impossible to achieve and, more often than not, smoke screens to hide what are really political decisions in support of the status quo. Inaction can have political consequences as far reaching as action." ${ }^{30}$ Our performance as archivists, our use of power, need to be opened to debate and to accountability. As Terry Cook and Joan Schwartz argue, "Power recognized becomes power that can be questioned, made accountable, and opened to transparent dialogue and enriched understanding." ${ }^{11}$ Once we acknowledge our bias we can avoid using this power indiscriminately or, even worse, accidentally.

Archivists have already made many thought-provoking suggestions on how to acknowledge and use the power of archives. Eric Ketelaar urges archivists to open their decision making to public scrutiny: "In a democracy, the debate about selection and access should be a public debate, subject to verification and control by the public." 32 Paraphrasing Abraham Lincoln, Ketelaar calls us to ensure "Archives of the people, by the people, for the people."33

Archivists' focus on the technical side of their duties sometimes obscures their social and cultural responsibilities. Shirley Spragge warned in 1994 of an emerging "abdication crisis of archivists' cultural responsibility." Too much emphasis on recordkeeping systems, accountability, and evidence, John Dirks adds, creates concern that "what could be termed as 'the right brain' of the archival mission - our cultural role in preserving heritage, and social memoryhas been unfairly neglected, sidelined, and even de-valued." In addition to holding accountable those leaders in politics, business, academics, and other fields whose records they manage, archivists themselves, Dirks reminds us, "will be held accountable by tomorrow's users, who depend on our making wellformulated, professional decisions that can stand the test of time. Indeed we are vital players, not passive observers, of the relationship between history, memory,

\footnotetext{
${ }^{30}$ Allan Spear, "Politics and the Professions," Midwestern Archivist 9, no. 2 (1984): 81.

${ }^{31}$ Cook and Schwartz, "Archives, Records, and Power," 181.

${ }^{32}$ Eric Ketelaar, The Archival Image (Hilversam: Verloren, 1997), 19.

${ }^{33}$ Ketelaar, Archival Image, 15.
} 
and accountability." 34 Power carries responsibility. It also raises the stakes of what archivists do and how we perform our roles.

Hilary Jenkinson set an unattainable ideal of the archivist as one who served researchers but never engaged in interpretation of the records. However, as Tom Nesmith asserts, "An act of interpretation is always at the heart of the management and use of documents." The archivist's role in society is "the assessment and protection of the integrity of the record as evidence." Nesmith adds, "Thus the utility, reliability, and authenticity of archival records are directly related to the ability of the archivist to interpret or contextualize records as fully as possible, rather than based simply on observing and guarding those attributes of records." 35

Accountability is at the heart of Orwell's fear of Big Brother's control over public memory. As Milan Kundera wrote of the Czechoslovakians' efforts to preserve their culture in the face of Soviet efforts to obliterate memories and compel the silence of his people, "The struggle of man against power is the struggle of memory against forgetting." 36 As Kenneth Foote observes, "For archivists, the idea of archives as memory is more than a metaphor. The documents and artifacts they collect are important resources for extending the spatial and temporal range of human communication." ${ }^{37}$ Archives provide essential benefits for society. "The care which the nation devotes to the preservation of the monuments of its past may serve as a true measure of the degree of civilization it has achieved," Waldo G. Leland declared in 1912. "The chief monument of the history of a nation is its archives, the preservation of which is recognized in all civilized countries as a natural and proper function of government." ${ }^{8}$ Archives not only hold public leaders accountable, they also enable all citizens to know the past.

\section{Social Responsibility}

Archives are therefore responsible to all citizens in a democratic society. They play an important function that often goes unnoticed. Archives document

\footnotetext{
${ }^{34}$ John M. Dirks, “Accountability, History, and Archives: Conflicting Priorities or Synthesized Strands?” Archivaria 57 (Spring 2004): 35, 49. Spragge quoted page 35.

${ }^{35}$ Tom Nesmith, "What's History Got to Do With It?: Reconsidering the Place of Historical Knowledge in Archival Work," Archivaria 57 (Spring 2004): 25-26.

${ }^{36}$ Milan Kundera, The Book of Laughter and Forgetting, quoted in David Thelen, "Memory and American History," Jourmal of American History 75 (March 1989): 1126.

${ }^{37}$ Kenneth E. Foote, “To Remember and Forget: Archives, Memory, and Culture," American Archivist 53 (Summer 1990): 393.

38 "Address by Waldo G. Leland, 1956," in Waldo G. Leland Papers, Manuscript Division, Library of Congress.
} 
and protect the rights of citizens. Examples abound of archival records being used in the public interest by holding public officials, corporate CEOs, university administrators, religious leaders, and others accountable for their actions. Archives and the Public Good: Accountability and Records in Modern Society, edited by Richard Cox and David Wallace, provides fascinating case studies reflecting the importance of records for accountability, access to information, and protection of the rights of all citizens. ${ }^{39}$ Even a partial list of topics is impressive: Nazi war criminals in Canada, the Iran-Contra affair, IRS policies, the Brown and Williamson tobacco case, the Tuskegee syphilis study, the South African state at the end of apartheid, and the history of United States foreign relations. More recently, Elizabeth Adkins has described the role of archives and documentary research in uncovering the truth behind Ford Motor Company's "use of forced and slave labor under the Nazi regime." 40

A generation ago, Gerald Ham challenged archivists to "provide the future with a representative record of human experience in our time," and to "hold up a mirror for mankind" so we could help people "understand the world they live in." ${ }^{41}$ Although we may be less sanguine now than then about our ability to do so, this is still a noble calling. At its heart, Ham's challenge was to represent all of society in our archives, to give voice to the poor, the impotent, and the obscure.

Archivists, both individually and collectively, must commit themselves to ensuring that our records document the lives and experiences of all groups in society, not just the political, economic, social, and intellectual elite. In 1971, Howard Zinn urged archivists to "take the trouble to compile a whole new world of documentary material, about the lives, desires, needs, of ordinary people." This would help ensure "that the condition, the grievances, the will of the underclasses become a force in the nation." 42

In responding to this challenge, archivists have made great strides. There are more archives devoted to-or at least concerned with-documenting women, racial and ethnic groups, laborers, the poor, gays and lesbians, and other marginalized peoples. We can still do more. I hope we will aspire to improve on our past successes. Archives also need to document the Christian right, the "silent majority," and extremist groups on both ends of the political spectrum, from the Ku Klux Klan and militia groups to eco-terrorists.

${ }^{39}$ Richard J. Cox and David A. Wallace, Archives and the Public Good: Accountability and Records in Modern Society (Westport, Conn.: Quorum Books, 2002).

${ }^{40}$ Elizabeth Adkins, "A History of the Ford Motor Company Archives, with Reflections on Archival Documentation of Ford of Europe's History," in Ford, 1903-2003: The European History, vol. 1: 24-25, ed. Hubert Bonin, Yannick Lung, and Steven Tolliday (Paris: PLAGE, 2003).

${ }^{41}$ F. Gerald Ham, "The Archival Edge," American Archivist 38 (January 1975): 5-13.

42 Zinn, "Secrecy, Archives, and the Public Interest," 25. 
Paying attention to the need for accountability and documentation serves the cause of human rights and social justice. "Archives not only aid in holding today's organizations legally and fiscally accountable to society, they also hold yesterday's leaders and institutions accountable, both in terms of morality and effectiveness," John Dirks claims. The availability of archives is essential to serve "a society's need for the prevalence of justice, and the preservation of rights, and values." 43 Archival records have been used to rehabilitate people wrongly convicted of crimes under a totalitarian regime and to obtain restitution from their former oppressor. ${ }^{44}$

As archivists we must strive, as Duff and Harris urge, "to investigate the aspects of records that are not being described, and the voices that are not being heard." However, in giving voice to the marginalized groups in society, they remind us that we must be careful not to inject our own biases and assumptions. "It is imperative that we not romanticize 'otherness,'" they insist. ${ }^{45}$

There is an inherent tension in documenting groups that have traditionally been neglected or marginalized. Who owns their history? The controversy over Native American graves and artifacts illustrates a problem of ownership that affects other groups in society. One reason that African Americans, ethnic groups, gays and lesbians, and others have created their own repositories is to retain control over their own documentation, over its presentation and interpretation, and over the very terms of access. Among Native Americans, for example, only specified families within a tribe are entitled to know about some rituals and traditions. The archival concept of open and equal access must be modified to respect such cultural traditions. ${ }^{46}$ Jeannette Bastian describes the loss of cultural memory suffered by the people of the Virgin Islands when the governmental records of Dutch and American colonial rulers were removed to those respective nations. Too narrow a definition of provenance led to a loss of control over the people's archives, history, and memory. ${ }^{47}$

Joel Wurl recounts an incident that vividly illustrates the power of archives to represent and protect the history and collective memory of a community. During the riots in Los Angeles following the Rodney King verdict, looters and

\footnotetext{
${ }^{43}$ Dirks, "Accountability, History, and Archives," 38.

${ }^{44}$ Ketelaar, “Archival Temples,” 230-31; John Fleckner, “'Dear Mary Jane': Some Reflections on Being an Archivist," American Archivist 54 (Winter 1991): 8-13; see also the extensive writings by Verne Harris on the archives of South Africa.

${ }^{45}$ Duff and Harris, "Stories and Names," 278-79.

${ }^{46}$ Conversation with Juanita Jefferson, archivist and records manager for Lummi Nation, 5 August 2005. See also Michael F. Brown, Who Owns Native Culture? (Cambridge, Mass.: Harvard University Press, 2003).

${ }^{47}$ Jeannette Allis Bastian, Owning Memory: How a Caribbean Community Lost Its Archives and Found Its History (Westport, Conn.: Greenwood Press, 2003).
} 
arsonists approached the Southern California Library for Social Studies and Research, a major repository depicting contemporary social justice movements and underrepresented communities. "Standing guard, Building Manager Chester Murray responded by telling them the library contained the history of African Americans, Latinos, and working class people and persuaded them to leave it alone. Many of the surrounding buildings were damaged or destroyed, but not the library." 48 As archivists, we must strive to be as effective as Chester Murray in explaining the importance of our archives and their social value.

SAA has responded to these challenges, but we can and must do more. We have spoken out against secrecy in government; against President Bush's Executive Order to control access to records of previous presidents; and against the excesses of the USA PATRIOT Act. We have joined legal proceedings to require open access to records of secret White House meetings, and to allow Unabomber Ted Kaczynski to give his papers to an archival repository. We have secured grant funds for "Strengthening Tribal Archives Programs," bringing fifteen archivists to SAA annual meetings. We have identified three strategic priorities: responding to the challenges of changing technology, ensuring that archives and our profession reflect the diversity of society, and enhancing public awareness of archives.

As we consider the symbolism and the substance of archives and the archival mission, let us embrace the power of archives. Let us accept the solemn obligation to use the Force for good and not for evil. Let us ensure that archives protect the public interest rather than the privileges of the powerful elites in society.

May our archival temples truly reflect values worthy of veneration and remembrance. May our archival prisons minimize locks and security and emphasize accountability, preservation, and access. May our menus be clear and understandable, and our table service efficient, thorough, and helpful.

This is what it means to be a profession. We must serve all sectors of society. Our goal should be to ensure archives of the people, by the people, and for the people. By embracing the power of archives, we can fulfill our proper role in society.

\footnotetext{
${ }^{48}$ Joel Wurl, "Ethnicity as Provenance: In Search of Values and Principles for Documenting the Immigrant Experience," paper presented at UCLA Center for Information as Evidence Forum, 20 April 2005, 2-3.
} 